\title{
Manipulating Planting Density and Nitrogen Fertilizer Application to Improve Yield and Reduce Environmental Impact in Chinese Maize Production
}

\author{
Cailong $X_{u^{1,2}, \text { Shoubing Huang }}{ }^{1}$, Beijing Tian', Jianhong Ren ${ }^{1}$, Qingfeng Meng ${ }^{1 *}$ and \\ Pu Wang ${ }^{1 *}$ \\ ${ }^{1}$ College of Agronomy and Biotechnology, China Agricultural University, Beijing, China, ${ }^{2}$ Institute of Crop Sciences, Chinese \\ Academy of Agricultural Sciences, Beijing, China
}

OPEN ACCESS

Edited by:

Marta Wilton Vasconcelos, Universidade Católica Portuguesa,

Portugal

Reviewed by:

Francis William Rayns,

Coventry University, United Kingdom Jiwang Zhang,

Shandong Agricultural University,

China

*Correspondence:

Qingfeng Meng

mengqf@cau.edu.cn

PuWang

wangpu@cau.edu.cn

Specialty section:

This article was submitted to Plant Nutrition,

a section of the journal

Frontiers in Plant Science

Received: 19 March 2017

Accepted: 29 June 2017

Published: 12 July 2017

Citation:

Xu C, Huang S, Tian B, Ren J,

Meng $Q$ and Wang P (2017)

Manipulating Planting Density and Nitrogen Fertilizer Application

to Improve Yield and Reduce Environmental Impact in Chinese

Maize Production

Front. Plant Sci. 8:1234.

doi: $10.3389 /$ fpls.2017.01234
Relatively low nitrogen $(\mathrm{N}$ ) efficiency and heavy environmental costs caused by excessive $\mathrm{N}$ fertilizer applications with outdated fertilization techniques are current cultivation production problems with maize among smallholders in North China Plain. Although many studies have examined agronomical strategies for improving yields and $\mathrm{N}$ use, the integrated effects of these measures and the associated environmental costs are not well understood. We conducted a 2-year field study with two densities $(67,500$ plants ha ${ }^{-1}$, which was similar to local farmers' practices, and 90,000 plants ha ${ }^{-1}$ ) and three $\mathrm{N}$ rates $\left(0,180\right.$, and $360 \mathrm{~kg} \mathrm{ha}^{-1}$, the rate local farmers' commonly apply) to test the integrated effects for maize production at Wuqiao experimental station in North China Plain. The higher planting density produced significant increases in grain yield (GY), N use efficiency (NUE), agronomic $\mathrm{N}$ efficiency (AEN), and $\mathrm{N}$ partial productivity $\left(\mathrm{PFP}_{\mathrm{N}}\right)$ by $6.6,3.9,24.7$, and $8.8 \%$, respectively; in addition, $\mathrm{N}_{2} \mathrm{O}$ emission and greenhouse gas intensity decreased by 7.3 and $4.3 \%$, respectively. With a lower $\mathrm{N}$ application rate, from 360 to $180 \mathrm{~kg} \mathrm{ha}^{-1}$, GY was unchanged, and NUE, AEN, and PFP $_{N}$ all significantly increased by $6.2,96.0$, and $98.7 \%$, respectively; in addition, $\mathrm{N}_{2} \mathrm{O}$ emission and greenhouse gas intensity decreased by 61.5 and $46.2 \%$, respectively. The optimized $\mathrm{N}$ rate $\left(180 \mathrm{~kg} \mathrm{~N}^{-1}\right.$ ) for the 90,000 plants ha ${ }^{-1}$ treatment achieved the highest yield with only $50 \%$ of the $\mathrm{N}$ fertilizer input commonly employed by local farmers' (360 $\mathrm{kg} \mathrm{N} \mathrm{ha}^{-1}$ ), which contributed to the increased N-uptake and N-transfer capacity. Therefore, our study demonstrated that agronomical methods such as increasing planting density with reasonable $\mathrm{N}$ application could be useful to obtain higher GY along with efficient $\mathrm{N}$ management to help lower environmental costs of maize production.

Keywords: high yield, high $\mathbf{N}$ use efficiency, greenhouse gas intensity, maize, sustainable

\section{INTRODUCTION}

To meet the increased demands of a burgeoning human population for food, feed, fiber, and biofuel, it has been estimated that agricultural production must increase by at least $50 \%$, and perhaps by as much as $110 \%$, relative to production in 2006 (Keyzer et al., 2005; Tester and Langridge, 2010; Tilman et al., 2011). In particular, the production of maize, a globally important crop, 
must roughly double to meet growing demands (Shiferaw et al., 2011). Nitrogen (N) is important nutrient to maximize crop growth, thus it is often applied to agricultural crops if available (Tilman et al., 2011). Although $\mathrm{N}$ fertilizer application can improve maize yields, if overused, it can also have negative environmental impacts such as groundwater pollution through nitrate leaching or increased global warming resulted to $\mathrm{N}_{2} \mathrm{O}$ emissions (Sylvester-Bradley and Kindred, 2009; Burney et al., 2010). Therefore, it is essential to understand the trade-offs between agronomic strategies and $\mathrm{N}$ application for crop productivity, nitrogen use efficiency (NUE), and environmental cost.

Winter wheat-summer maize double cropping is the main cropping system in the North China Plain, which accounts for about one third of national maize production. Significant crop production increases have been achieved through improved agronomic and nutrient management with various crop varieties (Grassini et al., 2011; Van Ittersum and Cassman, 2013; Van Ittersum et al., 2013). Planting density, i.e., number of plants per unit area, has proven to be a very effective agronomic strategy to improve maize grain yield (GY) (Tollenaar and Lee, 2002; Ciampitti and Vyn, 2012). For example, in the United States of America, average planting density increased from 30,000 plants $\mathrm{ha}^{-1}$ in the 1930 s to 45,000 plants ha ${ }^{-1}$ in the 1960s, and average maize yields increased from $2.3 \mathrm{Mg}$ $\mathrm{ha}^{-1}$ to $5.5 \mathrm{Mg} \mathrm{ha}^{-1}$; with increased planting densities from 55,000 plants $\mathrm{ha}^{-1}$ in the 1990 s to 97,500 plants $\mathrm{ha}^{-1}$ in the 2000s, maize yields increased from $9.0 \mathrm{Mg} \mathrm{ha}^{-1}$ to $15.0 \mathrm{Mg}$ $\mathrm{ha}^{-1}$ (Zhao and Wang, 2009). However, in China, in the 2000s, the average maize yield was only $5.4 \mathrm{Mg} \mathrm{ha}^{-1}$ at a planting density of 60,000 plants ha ${ }^{-1}$ (Li and Wang, 2009). High-yield records in maize production worldwide have been obtained under high planting densities. In United States, the highest maize GY was $33 \mathrm{Mg} \mathrm{ha}^{-1}$ with a planting density of 140,790 plants $\mathrm{ha}^{-1}$ in Charles City in 2015 (NCGA, 2017). In China, the highest maize GY was $19 \mathrm{Mg} \mathrm{ha}^{-1}$ with a planting density of 102,030 plants ha ${ }^{-1}$ in Shandong Province in 2005 (Li and Wang, 2009). Thus, density control as a means to influence yields is an important agronomic method to consider for maize production.

The $\mathrm{N}$ fertilizer application has also been used to increase crop yields globally (Miao et al., 2011; Linquist et al., 2013). For United States maize, GY increased from 4.5 to $6.0 \mathrm{Mg} \mathrm{ha}^{-1}$ with $\mathrm{N}$ application of 30-145 $\mathrm{kg} \mathrm{ha}^{-1}$ during 1960-1980, while the GY continually increased from 6.0 to $10 \mathrm{Mg} \mathrm{ha}^{-1}$ without further $\mathrm{N}$ input since 1980, and thus the $\mathrm{N}$ partial productivity $\left(\mathrm{PFP}_{\mathrm{N}}\right)$ increased by $36 \%$, from $42 \mathrm{~kg} \mathrm{~kg}^{-1}$ in 1980 to $57 \mathrm{~kg}$ $\mathrm{kg}^{-1}$ in 2000, at the end of 20th century (Cassman et al., 2002). The yield improvements were realized by adopting more efficient technologies and improved $\mathrm{N}$ fertilizer management (Pikul et al., 2005; Zhang et al., 2015). However, in China, $\mathrm{N}$ fertilizers are typically applied at levels, much higher than the uptake demand of crops, thus, environmental costs (i.e., $\mathrm{N}$ leaching $/ \mathrm{N}_{2} \mathrm{O}$ emissions) are increased (Zhang et al., 2008; Guo et al., 2010). The main greenhouse gas emitted from agricultural production, $\mathrm{N}_{2} \mathrm{O}$, is released from soils following the application of $\mathrm{N}$ fertilizer; it represents $38 \%$ of the total direct greenhouse gas emissions from global agriculture (Burney et al., 2010). The relationship between $\mathrm{N}_{2} \mathrm{O}$ and $\mathrm{N}$ fertilizers is usually demonstrated to be exponential (Hoben et al., 2011; Wang et al., 2014). Optimal $\mathrm{N}$ management improves crop yields, but it also contributes to higher NUE, thus reducing environmental costs (Chen et al., 2011; Cui et al., 2013). Therefore, it is urgent that we understand the relationship between increasing yields and the management of planting density and $\mathrm{N}$ application in an effort to balance agronomical and environmental objectives (e.g., reducing $\mathrm{N}_{2} \mathrm{O}$ emissions or greenhouse gas per unit crop yield) in an environmentally sustainable manner.

Some studies have reported that high maize GY through high NUE and relatively low $\mathrm{N}$ application were achieved under close planting because of high biomass or $\mathrm{N}$ accumulation and allocation to grain (Cui et al., 2009; Ciampitti et al., 2013). Moll et al. (1982) determined that $\mathrm{N}$ utilization can be divided into two processes: $\mathrm{N}$-uptake efficiency and $\mathrm{N}$-transfer efficiency. $\mathrm{N}$-uptake is a reflection of the capacity of the plant to recover $\mathrm{N}$ from fertilizer and soil (Moll et al., 1982; Foulkes et al., 2009) depending on the amount of root length density and the uninterrupted carbohydrate mobilization from shoot to root (Tolley-Henry et al., 1988; Rajcan and Tollenaar, 1999). The $\mathrm{N}$-transfer efficiency is the ability of the plant to transfer the $\mathrm{N}$ taken up by the crop into the grain during the grain-filling period (Moll et al., 1982; Foulkes et al., 2009). The vegetative organs, particularly the green leaf tissue, were the major storage organs for $\mathrm{N}, 49-53 \%$ of the total $\mathrm{N}$ accumulation at silking of maize, and the source of $\mathrm{N}$ for grain filling (Liu et al., 2014). Previous studies demonstrated that the absorption and remobilization of $\mathrm{N}$ in plants were both affected by planting density and N management (Ciampitti and Vyn, 2013; Kosgey et al., 2013). A more thorough study of planting and $\mathrm{N}$ management interactions is necessary to understand $\mathrm{N}$-uptake and $\mathrm{N}$-transfer responses and their relationship to final $\mathrm{N}$ utilization within maize plants.

The aim of this study was to examine the effect of planting density and $\mathrm{N}$ application rate on GY, $\mathrm{N}$ utilization, $\mathrm{N}_{2} \mathrm{O}$ emission intensity, and greenhouse gas intensity of summer maize in 2 years under field conditions. We also investigated the $\mathrm{N}$ accumulation and $\mathrm{N}$ remobilization of summer maize to elucidate the processes involved in increasing $\mathrm{N}$ utilization by optimizing planting density and $\mathrm{N}$ application rate.

\section{MATERIALS AND METHODS}

\section{Site Description}

Field experiments were carried out in 2014 and 2015 at the Wuqiao Experiment Station of China Agricultural University,

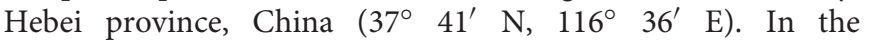
upper $0.4 \mathrm{~m}$ of the clay-loam soils, $\mathrm{pH}$ was 8.3 with a bulk density of $1.45 \mathrm{~g} \mathrm{~cm}^{-3}$, and they contained $12.36 \mathrm{~g}$ $\mathrm{kg}^{-1}$ of soil organic matter, $1.04 \mathrm{~g} \mathrm{~kg}^{-1}$ of total nitrogen $(\mathrm{N}), 37.71 \mathrm{mg} \mathrm{kg}^{-1}$ of readily available phosphorous (P), and $94.22 \mathrm{mg} \mathrm{kg}^{-1}$ of readily available potassium (K). The 
soil $\mathrm{pH}$, organic matter, total $\mathrm{N}$, available $\mathrm{P}$ and $\mathrm{K}$ were analyzed by following procedures of Piper (1950), Bremner (1965), Kjeldahl method, Stanford and English (1949) and Olsen et al. (1954), respectively. Preceding crop was winter wheat. A standard agro-meteorological station automatically recorded meteorological conditions in the experimental fields; air temperature and rainfall data during the study period growing seasons are provided in Figure 1. The light and temperature condition in 2015 was better than that in 2014, which benefited maize production.

\section{Experimental Design and Treatments}

The experimental design was a split-plot with three replicates: two planting densities treatments were applied as the main plots, and three $\mathrm{N}$ treatments were designated as sub-plots. The size of the main plot was $20 \mathrm{~m} \times 15 \mathrm{~m}$, and the sub-plot size was $20 \mathrm{~m} \times 5 \mathrm{~m}$. A common maize hybrid - Zhengdan 958, the main maize cultivar in NCP, was planted at two planting densities $\left(67,500\right.$ plants $\mathrm{ha}^{-1}$ and 90,000 plants ha $\left.{ }^{-1}\right)$ with equal row spacing of $0.6 \mathrm{~m}$. The $\mathrm{N}$ application rates were as follows: control (N0), $180 \mathrm{~kg} \mathrm{~N} \mathrm{ha}^{-1}$ (N180), and $360 \mathrm{~kg} \mathrm{~N}$ $\mathrm{ha}^{-1}$ (N360). As recommended by Liu et al. (2003), the N180 treatment was set in two stages: $90 \mathrm{~kg} \mathrm{~N} \mathrm{ha}^{-1}$ at the three-leaf stage and $90 \mathrm{~kg} \mathrm{~N} \mathrm{ha}^{-1}$ at the silking stage. The N360 treatment was set at $360 \mathrm{~kg} \mathrm{~N} \mathrm{ha}^{-1}$ at the time of planting; this is the traditional $\mathrm{N}$ management protocol used by farmers in NCP (Zhang et al., 2008). Urea was applied $0.1 \mathrm{~m}$ deep into the soil with a furrowing machine according to the $\mathrm{N}$ application rates. In addition, all plots received $130 \mathrm{~kg} \mathrm{P}_{2} \mathrm{O}_{5} \mathrm{ha}^{-1}$ in the form of calcium superphosphate $\left(\mathrm{P}_{2} \mathrm{O}_{5} 12 \%\right)$ and $130 \mathrm{~kg} \mathrm{~K}_{2} \mathrm{O}$ ha ${ }^{-1}$ in the form of potassium sulfate $\left(\mathrm{K}_{2} \mathrm{O} 60 \%\right)$ at the time of planting. Maize was planted on June 15, 2014 and on June 19, 2015, after winter wheat crops were harvested. Each plot was irrigated with $75 \mathrm{~mm}$ of water immediately after sowing. The maize grains were harvested on October 5 in both years before winter wheat planting.

\section{Plant Sampling and Analysis}

Three plant samples were randomly selected from the center of each plot during the silking stage and at the time of harvest. Plants were dissected into leaf + husk, stalk + cob, and grain (only at the time of harvest). All separated components were oven-dried at $80^{\circ} \mathrm{C}$ to a constant weight; they were then weighed to record dry matter accumulation (DMA, $\mathrm{kg} \mathrm{ha}^{-1}$ ) and milled into a powder. Total $\mathrm{N}$ was measured using the Kjeldahl method, and NUE (kg $\mathrm{kg}^{-1}$ ), agronomic $\mathrm{N}$ efficiency (AEN, $\mathrm{kg} \mathrm{kg}^{-1}$ ), and $\mathrm{N}$ partial productivity $\left(\mathrm{PFP}_{\mathrm{N}}, \mathrm{kg} \mathrm{kg}^{-1}\right)$ were calculated using the methods of Dobermann (2005).

$$
\begin{aligned}
\mathrm{NUE} & =\frac{\text { grain yield }}{\text { total } \mathrm{N} \text { uptake by plant }} \\
\mathrm{AEN} & =\frac{\text { grain yield with applied } \mathrm{N}-\text { grain yield without } \mathrm{N}}{\mathrm{N} \text { application amount }} \\
\mathrm{PFP}_{\mathrm{N}} & =\frac{\text { grain yield }}{\mathrm{N} \text { application amount }}
\end{aligned}
$$

Based on the DMA and $\mathrm{N}$ accumulation measurements, we calculated the following parameters (Mi et al., 2003; Chen Y. et al., 2014):

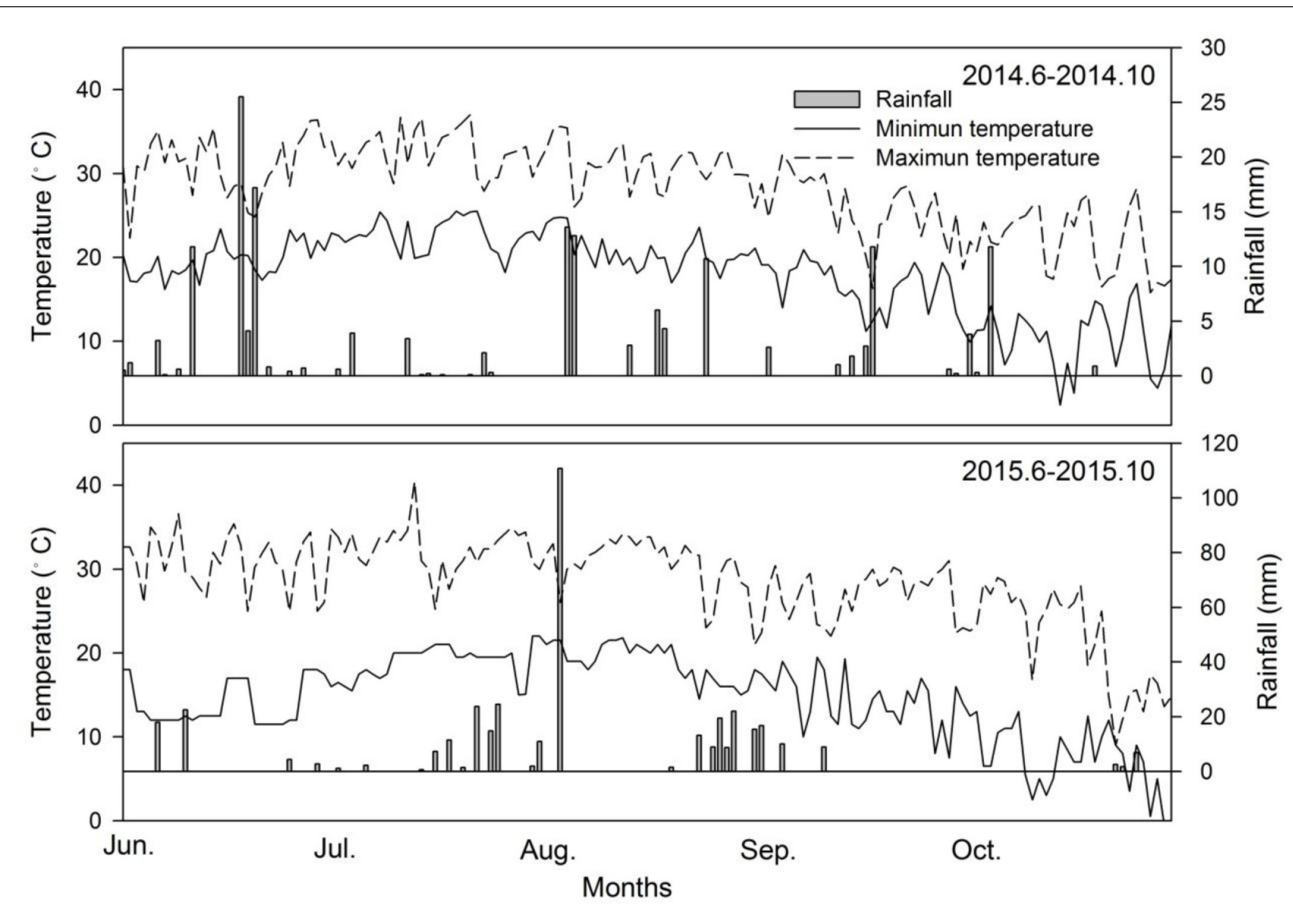

FIGURE 1 | Daily temperature and rainfall during the maize growing season in 2014 and 2015. 
Post silking DMA $\left(\mathrm{kg} \mathrm{ha}^{-1}\right)=$ DMA at harvest-DMA at silking $\mathrm{N}$ remobilization from vegetative organs to grain $\left(\mathrm{kg} \mathrm{ha}^{-1}\right)$ $=\mathrm{N}$ accumulation in vegetative organs at silking

$-\mathrm{N}$ accumulation in vegetative organs at harvest

$\mathrm{N}$ remobilization efficiency (\%)

$$
=\frac{\mathrm{N} \text { remobilization from vegetative organs to grain }}{\mathrm{N} \text { accumulation in vegetative organs at silking }}
$$

To determine the green leaf area at the silking stage and 10, 20, 30, 40, and 50 days after silking (DAS), leaf length ( $\mathrm{L}, \mathrm{cm})$, and maximum width $(\mathrm{W}, \mathrm{cm})$ were measured to calculate green leaf area (Montgomery, 1911) and leaf area index (LAI).

$$
\begin{aligned}
\text { Green leaf area }\left(\mathrm{cm}^{2}\right) & =0.75 \times \mathrm{L} \times \mathrm{W} \\
\text { Leaf area index } & =\frac{\text { total green area per plant }}{\text { land area per plant }}
\end{aligned}
$$

Direct $\mathrm{N}_{2} \mathrm{O}$ emission ( $\mathrm{kg} \mathrm{N} \mathrm{ha}{ }^{-1}$ ), $\mathrm{NH}_{3}$ volatilization $\left(\mathrm{kg} \mathrm{N} a^{-1}\right)$, and $\mathrm{NO}_{3}{ }^{-}$leaching $\left(\mathrm{kg} \mathrm{N}^{-1}\right)$ were calculated using the methods of Cui et al. (2013).

$$
\begin{aligned}
\text { Direct } \mathrm{N}_{2} \mathrm{O} \text { emission } & =0.48 \mathrm{e}^{0.0058 \mathrm{X}} \\
\mathrm{NH}_{3} \text { volatilization } & =0.24 \mathrm{X}+1.3 \\
\mathrm{NO}_{3} \text {-leaching } & =4.46 \mathrm{e}^{0.0094 \mathrm{X}}
\end{aligned}
$$

$\mathrm{X}$ is the $\mathrm{N}$ application rate $\left(\mathrm{kg} \mathrm{N} \mathrm{ha}^{-1}\right)$. The indirect $\mathrm{N}_{2} \mathrm{O}$ emissions can be estimated by following the IPCC methodology (IPCC, 2006) where 1 and $0.75 \%$ of the volatilized $\mathrm{N}-\mathrm{NH}_{3}$ and leached $\mathrm{N}_{-} \mathrm{NO}_{3}$ is lost as $\mathrm{N}_{2} \mathrm{O}-\mathrm{N}$. Using the above $\mathrm{N}$ loss- $\mathrm{N}$ input response curve, we calculated the direct, indirect, and total $\mathrm{N}_{2} \mathrm{O}$ emissions ( $\mathrm{kg} \mathrm{N}^{-1}$ ), and $\mathrm{N}_{2} \mathrm{O}$ emission intensity $\left(\mathrm{N}_{2} \mathrm{O}\right.$ emission per unit maize yield, $\mathrm{kg} \mathrm{N} \mathrm{Mg}^{-1}$ ).

Total greenhouse gas emissions (kg CO 2 eq; including $\mathrm{CO}_{2}$, $\mathrm{CH}_{4}$, and $\mathrm{N}_{2} \mathrm{O}$ ) during the life cycle of maize production are represented in three components: emissions during $\mathrm{N}$ fertilizer application; emissions during $\mathrm{N}$ fertilizer production and transportation; and emissions during the production and transportation of $\mathrm{P}$ and $\mathrm{K}$ fertilizer, and pesticides, and diesel fuel use in farming operations such as sowing, tilling, and harvesting. Components were calculated according to the methods of Cui et al. (2013).

Greenhouse gas emission during N use

$$
=298 \times \mathrm{N}_{2} \mathrm{O}_{\text {total }} \times 44 \div 28
$$

Greenhouse gas emission during $\mathrm{N}$ production $=\mathrm{N}_{\text {input }} \times 8.21$

Greenhouse gas emission during others pathway

$$
\begin{aligned}
& =\mathrm{P}_{2} \mathrm{O}_{\text {5input }} \times \mathrm{EF}_{\mathrm{p}}+\mathrm{K}_{2} \mathrm{O}_{\text {input }} \times \mathrm{EF}_{\mathrm{k}}+\text { Pest.input } \\
& \times \mathrm{EF}_{\text {pest. }}+\text { Fuel.input } \\
& \times \mathrm{EF}_{\text {fuel. }}+9.2 \times \text { Irri. } \times \mathrm{EF}_{\text {elec. }} .
\end{aligned}
$$

$\mathrm{EF}$ in the equation 14 is coefficient of greenhouse gas emissions. The values of $\mathrm{EF}_{\mathrm{p}}, \mathrm{EF}_{\mathrm{k}}, \mathrm{EF}_{\text {pest. }}, \mathrm{EF}_{\text {fuel., }}$ and $\mathrm{EF}_{\text {elec. }}$ were $0.79,0.55,19.13,3.75$, and $1.14 \mathrm{~kg} \mathrm{CO}_{2}$ eq per unit input, respectively. The value of Pest.input and Fuel.input were estimated to be 4.13 and $72.7 \mathrm{~kg} \mathrm{ha}^{-1}$, respectively. We then calculated the total greenhouse gas emission (also known as global warming potential, $\left.\mathrm{kg} \mathrm{CO}_{2} \mathrm{eq} \mathrm{ha}^{-1}\right)$ and greenhouse gas intensity $\left(\mathrm{kg} \mathrm{CO}_{2}\right.$ eq $\left.\mathrm{Mg}^{-1}\right)$.

At the time of harvest, maize GY (14\% water content) was measured within a randomly selected $7.2 \mathrm{~m}^{2}$ sub-plot $(4 \mathrm{~m} \times 1.8 \mathrm{~m})$ in each plot. Kernel number was measured on 10 randomly selected ears from each plot. Thousand-kernel weight (TKW) was determined after drying thousand-kernel samples at $80^{\circ} \mathrm{C}$ in a forced-draft convention oven to a constant weight.

\section{Data Analysis}

The effects of the treatments and years on the measured parameters [including GY, $\mathrm{N}$ utilization, $\mathrm{N}_{2} \mathrm{O}$ emission intensity, and greenhouse gas intensity] were evaluated using univariate analysis of variance (ANOVA) procedures. After verifying the homogeneity of error variances, all the data across planting densities and $\mathrm{N}$ application rates were pooled for use in the ANOVA. Differences were compared using the least significant difference test (LSD) at a 0.05 level of probability. All analyses were conducted using SPSS 17.0 (SPSS Inc., Chicago, IL, United States).

\section{RESULTS}

\section{Grain Yield and Yield Components}

Grain yields and yield components were significantly affected by planting density, $\mathrm{N}$ application rate, and the interaction of planting density $\times \mathrm{N}$ application rate (Table 1 and Supplementary Figure S1). As planting density increased from 67,500 to 90,000 plants $\mathrm{ha}^{-1}$, GY was significantly increased by $7 \%$ (from $9,556.5$ to $10,184.5 \mathrm{~kg} \mathrm{ha}^{-1}$ ) across years and $\mathrm{N}$ application rates. No significant difference in GY was observed between N180 and N360 treatments across years and two densities (Table 1).

Increased planting density produced a significant $23 \%$ increase of average ear number; kernel number and TKW displayed significant decreases of 7 and 4\%, respectively (Table 1). No significant differences in the three yield components were observed between N180 and N360 treatments.

\section{Nitrogen Utilization}

Planting density, $\mathrm{N}$ application rate, and the interaction of planting density $\times \mathrm{N}$ application rate had a significantly influence on NUE, AEN and $\mathrm{PFP}_{\mathrm{N}}$ (Table 2 and Supplementary Figure S2). As planting density increased from 67,500 to 90,000 plants ha ${ }^{-1}$, NUE, AEN, and $\mathrm{PFP}_{\mathrm{N}}$ significantly increased by 4,25 , and $9 \%$, respectively. Across years and planting densities, the average NUE was ranked in the following order: $44.4 \mathrm{~kg} \mathrm{~kg}^{-1}$ for $\mathrm{N} 180>41.8 \mathrm{~kg} \mathrm{~kg}^{-1}$ for $\mathrm{N} 360>32.5 \mathrm{~kg}$ $\mathrm{kg}^{-1}$ for $\mathrm{N} 0$. The AEN and $\mathrm{PFP}_{\mathrm{N}}$ in $\mathrm{N} 180$ were 24.7 and $63.0 \mathrm{~kg} \mathrm{~kg}^{-1}$, respectively, which displayed significant 
TABLE 1 | Grain yield and yield components of summer maize for planting densities of 67,500 (D67500) and 90,000 plants ha ${ }^{-1}$ (D90000) and $\mathrm{N}$ treatments of 0 (N0), 180 (N180), and $360 \mathrm{~kg} \mathrm{~N} \mathrm{ha}^{-1}$ (N360) in 2014 and 2015.

\begin{tabular}{|c|c|c|c|c|}
\hline Treatments & $\begin{array}{c}\text { Kernels } \\
\left(\text { No. ear }{ }^{-1}\right)\end{array}$ & TKW (g) & $\begin{array}{c}\text { Ear } \\
\left(\text { No. } \text { ha }^{-1}\right)\end{array}$ & $\begin{array}{c}\text { Grain yield } \\
\left(\mathrm{kg} \mathrm{ha}^{-1}\right)\end{array}$ \\
\hline \multicolumn{5}{|l|}{ Year } \\
\hline 2014 & $474.7 \mathrm{a}^{\dagger}$ & 283.0b & $75930.2 a$ & $9646.7 a$ \\
\hline 2015 & $476.4 \mathrm{a}$ & 299.3a & $76774.7 a$ & $10094.2 \mathrm{a}$ \\
\hline \multicolumn{5}{|c|}{ Density (plants ha ${ }^{-1}$ ) } \\
\hline D67500 & $492.0 a$ & $296.9 a$ & $68371.6 \mathrm{~b}$ & $9556.5 b$ \\
\hline D90000 & 459.0b & $285.4 b$ & 84333.3a & $10184.5 \mathrm{a}$ \\
\hline \multicolumn{5}{|c|}{ Nitrogen (kg N ha ${ }^{-1}$ ) } \\
\hline NO & $417.2 \mathrm{~b}$ & $286.9 b$ & $74714.8 b$ & $6879.4 b$ \\
\hline N180 & $507.6 a$ & $290.6 a b$ & $77213.0 \mathrm{a}$ & $11331.5 \mathrm{a}$ \\
\hline N360 & $501.8 a$ & $295.9 a$ & $77129.6 a$ & $11400.6 a$ \\
\hline \multicolumn{5}{|c|}{ Source of variation } \\
\hline Year $(Y)$ & NS & $* * *$ & NS & $*$ \\
\hline Density (D) & $* * *$ & $* * *$ & $* * *$ & $* *$ \\
\hline Nitrogen (N) & $* * *$ & $* * *$ & $* *$ & $* * *$ \\
\hline$Y \times D$ & NS & NS & NS & NS \\
\hline$Y \times N$ & NS & NS & NS & NS \\
\hline $\mathrm{D} \times \mathrm{N}$ & NS & NS & $* *$ & $*$ \\
\hline $\mathrm{Y} \times \mathrm{D} \times \mathrm{N}$ & NS & NS & NS & NS \\
\hline
\end{tabular}

†Different letters within year, density or nitrogen indicate significant differences $(P<0.05)$. NS, no significant $(P>0.05)$. TKW, thousand-kernel weight. * Significant at $P<0.05$. ${ }^{* *}$ Significant at $P<0.01$. ${ }^{* * *}$ Significant at $P<0.001$.

increases of 96 and 99\%, respectively, compared to N360 (Table 2).

\section{Nitrogen Accumulation}

Planting density and $\mathrm{N}$ application rate had a significant influence on $\mathrm{N}$ accumulation at silking and harvest, and the $\mathrm{N}$ distribution ratio at the time of harvest (Tables 3,4 ).

As planting density increased from 67,500 to 90,000 plants ha ${ }^{-1}, \mathrm{~N}$ accumulation at silking and harvest of summer maize were significantly increased by 11 and $3 \%$, respectively, across years and $\mathrm{N}$ applying rates. At silking, a planting density of 90,000 plants $\mathrm{ha}^{-1}$ displayed increases in $\mathrm{N}$ accumulation in leaf + husk and stalk + cob of 8 and $16 \%$, respectively, relative to a summer maize planted at a density of 67,500 plants ha ${ }^{-1}$. At harvest, the higher planting density resulted in significantly increased $\mathrm{N}$ accumulation in grains, however, the $\mathrm{N}$ accumulation in leaf + husk and stalk + cob were decreased by 4 and $5 \%$, respectively (Tables 3, 4).

Across years and planting densities, we observed increased total $\mathrm{N}$ accumulation at silking, $\mathrm{N}$ accumulation in each organ at silking, total $\mathrm{N}$ accumulation at harvest, and $\mathrm{N}$ accumulation in each organ at harvest with increasing $\mathrm{N}$ application rates (Tables 3, 4).

\section{Nitrogen Remobilization}

Planting density, $\mathrm{N}$ application rate, and the interaction of planting density $\times \mathrm{N}$ application rate significantly influenced $\mathrm{N}$
TABLE 2 | Nitrogen use efficiency (NUE), agronomic $\mathrm{N}$ efficiency (AEN), and $\mathrm{N}$ partial factor productivity $\left(\right.$ PFP $_{N}$ ) of summer maize for planting densities of 67,500 (D67500) and 90,000 plants ha ${ }^{-1}$ (D90000) and $\mathrm{N}$ treatments of 0 (N0), 180 (N180), and $360 \mathrm{~kg} \mathrm{~N} \mathrm{ha}^{-1}$ (N360) in 2014 and 2015

\begin{tabular}{|c|c|c|c|}
\hline Treatments & NUE (kg kg $\left.{ }^{-1}\right)$ & AEN (kg kg $\left.{ }^{-1}\right)$ & $\operatorname{PFP}_{\mathrm{N}}\left(\mathrm{kg} \mathrm{kg}^{-1}\right)$ \\
\hline \multicolumn{4}{|l|}{ Year } \\
\hline 2014 & $37.6 \mathrm{~b}^{\dagger}$ & $17.9 a$ & $46.1 \mathrm{a}$ \\
\hline 2015 & $41.6 a$ & $19.4 a$ & $48.5 a$ \\
\hline \multicolumn{4}{|c|}{ Density (plants ha ${ }^{-1}$ ) } \\
\hline D67500 & $38.8 b$ & $16.6 b$ & $45.3 b$ \\
\hline D90000 & $40.3 a$ & $20.7 a$ & $49.3 a$ \\
\hline \multicolumn{4}{|c|}{ Nitrogen (kg N ha-1) } \\
\hline NO & $32.5 c$ & & \\
\hline N180 & $44.4 a$ & $24.7 a$ & $63.0 \mathrm{a}$ \\
\hline N360 & $41.8 b$ & $12.6 b$ & $31.7 \mathrm{~b}$ \\
\hline \multicolumn{4}{|c|}{ Source of variation } \\
\hline Year $(Y)$ & $* * *$ & NS & NS \\
\hline Density (D) & $* *$ & $* * *$ & $* * *$ \\
\hline Nitrogen (N) & $* * *$ & $* * *$ & $* * *$ \\
\hline$Y \times D$ & NS & NS & NS \\
\hline $\mathrm{Y} \times \mathrm{N}$ & NS & NS & NS \\
\hline$D \times N$ & $* * *$ & NS & NS \\
\hline $\mathrm{Y} \times \mathrm{D} \times \mathrm{N}$ & NS & NS & NS \\
\hline
\end{tabular}

${ }^{\dagger}$ Different letters within year, density or nitrogen indicate significant differences $(P<0.05)$. NS, no significant $(P>0.05)$. ${ }^{* *}$ Significant at $P<0.01 .{ }^{* *}$ Significant at $P<0.001$.

remobilization and $\mathrm{N}$ remobilization efficiency from vegetative organ to grain after silking (Table 4).

$\mathrm{N}$ remobilization of total, leaf + husk, and stalk + cob was increased by 34,21 , and $39 \%$ as planting density increased from 67,500 to 90,000 plants $\mathrm{ha}^{-1}$, respectively; in addition, $\mathrm{N}$ remobilization efficiency of total, leaf + husk, and stalk + cob was also increased by 21,13 , and $41 \%$, respectively (Table 4 ). No significant differences in $\mathrm{N}$ remobilization of total, leaf + husk, and stalk + cob were observed between N180 and N360 treatments. However, $\mathrm{N}$ remobilization efficiency of total, leaf + husk, and stalk + cob in N360 treatment was decreased by 2,11 , and $5 \%$ relative to summer maize of N180 treatment (Table 4).

\section{Dry Matter Accumulation and Leaf Area Index}

Pre-silking, post-silking, and total DMA were significantly affected by planting densities and $\mathrm{N}$ application rates (Table 5 and Supplementary Figure S3).

With the higher planting density, the pre-silking, postsilking, and total DMA were significantly increased by 11 , 4 , and $6 \%$, respectively, across years and $\mathrm{N}$ application rates. The post-silking and total DMA were significantly increased by $\mathrm{N}$ application, but we observed no significant differences in pre-silking, post-silking, and total DMA when comparing N180 and N360 treatments (Table 5). In addition, significant positive correlations were observed between $\mathrm{N}$ accumulation and DMA at harvest in both planting densities (Figure 2). 
TABLE 3 | Nitrogen accumulation and distribution ratio at harvest of summer maize for planting densities of 67,500 (D67500) and 90,000 plants ha ${ }^{-1}$ (D90000) and $\mathrm{N}^{-1}$ treatments of 0 (N0), 180 (N180), and $360 \mathrm{~kg} \mathrm{~N} \mathrm{ha}^{-1}$ (N360) in 2014 and 2015.

\begin{tabular}{|c|c|c|c|c|c|c|c|}
\hline \multirow[t]{2}{*}{ Treatments } & \multicolumn{4}{|c|}{$\mathrm{N}$ accumulation $\left(\mathrm{kg} \mathrm{ha}^{-1}\right)$} & \multicolumn{3}{|c|}{$\mathrm{N}$ distribution ratio (\%) } \\
\hline & Grain & Leaf + husk & Stalk + cob & Total & Grain & Leaf + husk & Stalk + cob \\
\hline \multicolumn{8}{|l|}{ Year } \\
\hline 2014 & $163.6 \mathrm{a}^{\dagger}$ & $47.5 \mathrm{a}$ & $44.9 a$ & $254.5 a$ & $64.4 \mathrm{a}$ & $18.6 \mathrm{a}$ & $17.6 \mathrm{a}$ \\
\hline 2015 & $152.2 \mathrm{~b}$ & $44.2 b$ & $42.2 b$ & $238.5 b$ & $63.9 b$ & $18.5 \mathrm{a}$ & $17.7 \mathrm{a}$ \\
\hline \multicolumn{8}{|c|}{ Density (plants ha ${ }^{-1}$ ) } \\
\hline D67500 & $152.8 b$ & $46.8 \mathrm{a}$ & $44.6 a$ & $243.4 b$ & $62.8 \mathrm{~b}$ & $19.2 \mathrm{a}$ & $18.3 a$ \\
\hline D90000 & $163.0 \mathrm{a}$ & $44.8 \mathrm{~b}$ & $42.5 b$ & $249.6 a$ & $65.5 a$ & $17.8 \mathrm{~b}$ & $17.0 \mathrm{~b}$ \\
\hline \multicolumn{8}{|c|}{ Nitrogen (kg N ha-1) } \\
\hline NO & $138.7 c$ & $37.2 \mathrm{c}$ & $36.1 \mathrm{c}$ & $211.3 c$ & $65.6 a$ & $17.7 \mathrm{c}$ & $17.1 b$ \\
\hline N180 & $163.0 b$ & $46.6 b$ & $45.0 \mathrm{~b}$ & $254.6 b$ & $64.0 \mathrm{~b}$ & $18.3 b$ & $17.7 \mathrm{a}$ \\
\hline N360 & 172.0a & $53.7 \mathrm{a}$ & $49.5 a$ & $273.7 a$ & $62.8 \mathrm{c}$ & $19.6 a$ & $18.1 \mathrm{a}$ \\
\hline \multicolumn{8}{|c|}{ Source of variation } \\
\hline Year (Y) & $* * *$ & $* * *$ & $* * *$ & $* * *$ & $* *$ & NS & NS \\
\hline Density (D) & $* * *$ & $* * *$ & $* * *$ & $* * *$ & $* * *$ & $* * *$ & $* * *$ \\
\hline Nitrogen (N) & $* * *$ & $* * *$ & $* * *$ & $* * *$ & $* * *$ & $* * *$ & $* * *$ \\
\hline$Y \times D$ & $* *$ & NS & NS & $* *$ & NS & NS & NS \\
\hline$Y \times N$ & $* * *$ & $*$ & $*$ & $* * *$ & NS & NS & NS \\
\hline $\mathrm{D} \times \mathrm{N}$ & $* * *$ & $* * *$ & $*$ & $* * *$ & $* * *$ & $* * *$ & NS \\
\hline$Y \times D \times N$ & $* *$ & $*$ & $* *$ & $* * *$ & NS & NS & NS \\
\hline
\end{tabular}

${ }^{\dagger}$ Different letters within year, density or nitrogen indicate significant differences $(P<0.05)$. NS, no significant $(P>0.05)$. ${ }^{*}$ Significant at $P<0.05 . * *$ Significant at $P<0.01$. *** Significant at $P<0.001$.

The LAI of maize gradually decreased after silking. The LAI after silking in N360 treatment was always higher than that in N180 treatment under both planting densities. Given the same $\mathrm{N}$ application rate, the LAI in planting density of 90,000 plants $\mathrm{ha}^{-1}$ was always higher (Figure 3 ). In addition, significant negative correlations were observed between $\mathrm{N}$ remobilization efficiency and LAI at harvest in both planting densities (Figure 4).

\section{$\mathrm{N}_{2} \mathrm{O}$ Emission Intensity and Greenhouse Gas Intensity}

$\mathrm{N}_{2} \mathrm{O}$ emission intensity and greenhouse gas intensity were both strongly affected by planting density, $\mathrm{N}$ application rate, and the interaction of planting density $\times \mathrm{N}$ application rate (Table 6 and Supplementary Figure S4).

As planting density increased from 67,500 to 90,000 plants ha-1, the direct, indirect, and total $\mathrm{N}_{2} \mathrm{O}$ emission intensity were significantly decreased by 7,8 , and 7\%, respectively, across years and $\mathrm{N}$ application rates. The direct, indirect, and total $\mathrm{N}_{2} \mathrm{O}$ emission intensity were significantly increased by $\mathrm{N}$ application. The direct, indirect, and total $\mathrm{N}_{2} \mathrm{O}$ emission intensity in $\mathrm{N} 360$ treatments were significantly increased by 182,198 , and $187 \%$, respectively, relative to the N180 treatment (Table 6). The higher planting density also produced significantly lower (4\%) greenhouse gas intensity across years and $\mathrm{N}$ application rates. Greenhouse gas intensity significantly increased with $\mathrm{N}$ application; we observed a significant increase of $86 \%$ in greenhouse gas intensity in the N360 treatment compared to the N180 treatment (Table 6).

\section{DISCUSSION}

\section{Effects of Planting Density and Nitrogen Application Rate on Grain Yield}

Selecting high-yield maize varieties that are tolerant of high planting densities has become an increasingly popular field of research for breeders (Troyer and Rosenbrook, 1983; Tollenaar and Lee, 2002). Previous studies have reported that increases in maize yields are mainly dependent on the breeding of high-yield varieties and high planting densities (Tokatlidis et al., 2011; Van Ittersum and Cassman, 2013). In this study, GY was significantly higher at a planting density of 90,000 plants $\mathrm{ha}^{-1}$ (Table 1 and Supplementary Figure S1), which is much higher than the planting densities typically employed by local farmers $\left(<60,000\right.$ plants $h^{-1}$; Chen et al., 2009) and more comparable to planting densities commonly used in North America $\left(>80,000\right.$ plants ha ${ }^{-1}$; Lee and Tollenaar, 2007). However, the kernel number and TKW were decreased (Table 1), which was in agreement with most previous studies (Andrade et al., 2002; Borrás et al., 2004). Under high planting density, interplant competition for resources is exacerbated, which produces a lower number of kernel per ear and lower TKW (Tollenaar et al., 2006; Boomsma et al., 2009); GY increases are attributable to the increased number of ear 
TABLE 4 | Nitrogen accumulation of vegetative organs at silking, and its remobilization and remobilization efficiency to grain after silking of summer maize for planting densities of 67,500 (D67500) and 90,000 plants ha-1 (D90000) and N treatments of 0 (N0), 180 (N180), and 360 kg N ha-1 (N360) in 2014 and 2015.

\begin{tabular}{|c|c|c|c|c|c|c|c|c|c|}
\hline \multirow[t]{2}{*}{ Treatments } & \multicolumn{3}{|c|}{$\mathrm{N}$ accumulation $\left(\mathrm{kg} \mathrm{ha}^{-1}\right)$} & \multicolumn{3}{|c|}{$\mathrm{N}$ remobilization $\left(\mathrm{kg} \mathrm{ha}^{-1}\right)$} & \multicolumn{3}{|c|}{$\mathrm{N}$ remobilization Efficiency (\%) } \\
\hline & Leaf + husk & Stalk + cob & Total & Leaf + husk & Stalk + cob & Total & Leaf + husk & Stalk + cob & Total \\
\hline \multicolumn{10}{|l|}{ Year } \\
\hline 2014 & $85.3 \mathrm{~b}^{\dagger}$ & $64.6 b$ & $150.0 b$ & $41.1 b$ & $22.5 b$ & $63.5 b$ & $48.4 b$ & $34.7 b$ & $42.5 b$ \\
\hline 2015 & $97.0 \mathrm{a}$ & $71.5 \mathrm{a}$ & $168.5 \mathrm{a}$ & $49.5 a$ & $26.6 a$ & $76.2 \mathrm{a}$ & $51.1 \mathrm{a}$ & $36.9 a$ & $45.1 \mathrm{a}$ \\
\hline \multicolumn{10}{|c|}{ Density (plants ha-1) } \\
\hline D67500 & $87.8 \mathrm{~b}$ & $63.2 b$ & $151.0 b$ & $41.0 \mathrm{~b}$ & $18.6 b$ & $59.6 b$ & $46.8 b$ & $29.7 b$ & $39.6 b$ \\
\hline D90000 & $94.5 \mathrm{a}$ & $73.0 \mathrm{a}$ & $167.4 \mathrm{a}$ & $49.6 a$ & $30.4 a$ & $80.1 \mathrm{a}$ & $52.7 a$ & $41.9 a$ & $48.0 \mathrm{a}$ \\
\hline \multicolumn{10}{|c|}{ Nitrogen (kg N ha-1) } \\
\hline NO & $83.3 c$ & $63.5 c$ & $146.8 \mathrm{c}$ & $42.5 b$ & $22.8 b$ & $65.3 b$ & $51.0 \mathrm{a}$ & $39.5 a$ & $45.5 \mathrm{a}$ \\
\hline N180 & $89.0 b$ & $67.8 b$ & $157.0 \mathrm{~b}$ & $47.4 a$ & $25.4 a$ & $72.8 \mathrm{a}$ & $53.3 a$ & $37.5 a$ & 43.4ab \\
\hline N360 & $101.1 \mathrm{a}$ & $72.9 a$ & 174.0a & $48.1 \mathrm{a}$ & $25.9 a$ & $74.0 \mathrm{a}$ & $47.6 b$ & $35.5 b$ & $42.5 b$ \\
\hline \multicolumn{10}{|c|}{ Source of variation } \\
\hline Year $(Y)$ & $* * *$ & $* * *$ & $* * *$ & $* * *$ & $* * *$ & $* * *$ & $* * *$ & $* * *$ & $* * *$ \\
\hline Density (D) & $* * *$ & $* * *$ & $* * *$ & $* * *$ & $* * *$ & $* * *$ & $* * *$ & $* * *$ & $* * *$ \\
\hline Nitrogen (N) & $* * *$ & $* * *$ & $* * *$ & $* * *$ & $* * *$ & $* * *$ & $* * *$ & $* * *$ & $* * *$ \\
\hline$Y \times D$ & NS & $* *$ & $* *$ & $*$ & $* *$ & $* *$ & NS & NS & NS \\
\hline$Y \times N$ & NS & $* *$ & $* *$ & NS & $*$ & NS & NS & NS & NS \\
\hline $\mathrm{D} \times \mathrm{N}$ & $* *$ & $* * *$ & $* * *$ & $*$ & $* * *$ & $* *$ & $* *$ & $* * *$ & NS \\
\hline $\mathrm{Y} \times \mathrm{D} \times \mathrm{N}$ & NS & $*$ & NS & NS & NS & NS & NS & NS & NS \\
\hline
\end{tabular}

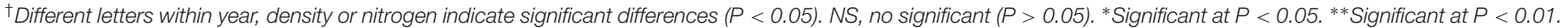
*** Significant at $P<0.001$.

per area (Grassini et al., 2011; Van Ittersum and Cassman, 2013). Thus, for GY, the positive effects of high planting densities surpassed the negative effects of interplant competition. Improving kernels per ear and TKW are two potential paths to increase maize yields in high planting density conditions in the future.

Nitrogen can affect crop yields through its influence on the yield components (kernel per ear, TKW, and ear per unit area; Raun and Jhonson, 1999; Van Ittersum and Cassman, 2013). In this study, the GY and yield components were significantly increased by the application of $\mathrm{N}$ (N180 and N360 $\mathrm{kg} \mathrm{N} \mathrm{ha}^{-1}$ ); however, we observed no significant differences in maize GY and yield components between $\mathrm{N} 180$ and $\mathrm{N} 360 \mathrm{~kg} \mathrm{~N} \mathrm{ha}{ }^{-1}$ treatments (Table 1). These observations are consistent with previous studies demonstrating that the response of maize GY to increasing $\mathrm{N}$ apply followed a parabolic curvilinear relationship (Cui et al., 2009; Meng et al., 2013). Previous studies have demonstrated that the metabolism of $\mathrm{N}$ and carbon in plants are affected by the activity of nitrate reductase (NR) and sucrose phosphate synthetase (SPS; Lawlor and Cornic, 2002; Shen et al., 2007). The activity of these two enzymes shows an increasing trend with increased $\mathrm{N}$ applications within a certain range, thus, they enhance the accumulation of photoproduct and transshipment; however, the activity of SPS decreases when the $\mathrm{N}$ is excessively applied, which can explain observed decreases in the number of kernel per ear and TKW (Shen et al., 2007; Li et al., 2012), leading to low GY (Table 1 and Supplementary Figure S1).

\section{Effects of Planting Density and Nitrogen Application Rate on Nitrogen Utilization}

Nitrogen utilization can be increased by better-integrated agronomic management practices, such as fertilizing and crop cultivation techniques, which can better ensure maximized crop production and $\mathrm{N}$ efficiency (Chen et al., 2006; Cui et al., 2009). Our results demonstrated that high NUE, AEN, and $\mathrm{PFP}_{\mathrm{N}}$ are obtainable through increased planting density (from 67,500 to 90,000 plants $\mathrm{ha}^{-1}$ ) or decreased $\mathrm{N}$ applications (from 360 to $180 \mathrm{~kg} \mathrm{~N} \mathrm{ha}^{-1}$; Table 2 and Supplementary Figure S2). Using the same $\mathrm{N}$ application rate, the highest NUE, $A E N$, and $\mathrm{PFP}_{\mathrm{N}}$ values were obtained with a planting density of 90,000 plants $\mathrm{ha}^{-1}$; using the same planting density, the highest NUE, AEN, and $\mathrm{PFP}_{\mathrm{N}}$ values were both obtained in the N180 treatment. The highest NUE, AEN, and $\mathrm{PFP}_{\mathrm{N}}$ values among the six treatments were obtained at a planting density of 90,000 plants $\mathrm{ha}^{-1}$ with an $\mathrm{N}$ application rate of $180 \mathrm{~kg} \mathrm{~N} \mathrm{ha}^{-1}$ (Supplementary Figure S2), which is comparable to the recommended high-yield maize in China $\left(100,000\right.$ plants ha ${ }^{-1}$ with $237 \mathrm{~kg} \mathrm{~N}^{-1}$; Chen et al., 2011) and in Nebraska, United States (75,000 plants $\mathrm{ha}^{-1}$ with $183 \mathrm{~kg} \mathrm{~N}^{-1}$; Grassini et al., 2011).

For $\mathrm{N}$ absorption, the correlation analysis indicated that $\mathrm{N}$ accumulation had a significant and positive relationship with DMA (Figure 2). This is consistent with previous studies that demonstrated that $\mathrm{N}$-uptake and DMA improved simultaneously (Liu et al., 2014). In this study, DMA was greater with higher planting density and $\mathrm{N}$ application rates 
TABLE 5 | Pre- and post-silking dry matter accumulation of summer maize for planting densities of 67,500 (67500) and 90,000 plants ha ${ }^{-1}$ (D90000) and $\mathrm{N}$ treatments of 0 (N0), 180 (N180), and $360 \mathrm{~kg} \mathrm{~N} \mathrm{ha}^{-1}$ (N360) in 2014 and 2015.

\begin{tabular}{|c|c|c|c|}
\hline \multirow[t]{2}{*}{ Treatments } & \multicolumn{3}{|c|}{ Dry matter accumulation (kg ha-1) } \\
\hline & Pre-silking & Post-silking & Total \\
\hline \multicolumn{4}{|l|}{ Year } \\
\hline 2014 & $7676.5 \mathrm{a}^{\dagger}$ & $12466.9 a$ & $20143.4 \mathrm{a}$ \\
\hline 2015 & $7543.4 a$ & $12432.3 a$ & $19975.7 a$ \\
\hline \multicolumn{4}{|c|}{ Density (plants ha-1) } \\
\hline D67500 & $7222.5 b$ & $12225.1 b$ & $19447.6 b$ \\
\hline D90000 & $7997.4 a$ & $12674.1 \mathrm{a}$ & $20671.5 a$ \\
\hline \multicolumn{4}{|c|}{ Nitrogen (kg N ha ${ }^{-1}$ ) } \\
\hline NO & $7070.5 b$ & $11194.2 b$ & $18264.7 b$ \\
\hline N180 & 7490.4ab & $13228.4 a$ & $20718.9 a$ \\
\hline N360 & $8268.9 \mathrm{a}$ & $12926.2 a$ & $21195.1 \mathrm{a}$ \\
\hline \multicolumn{4}{|c|}{ Source of variation } \\
\hline Year $(Y)$ & NS & NS & NS \\
\hline Density (D) & $*$ & $* *$ & $* *$ \\
\hline Nitrogen (N) & $*$ & $* * *$ & $* * *$ \\
\hline$Y \times D$ & NS & NS & NS \\
\hline$Y \times N$ & NS & NS & $* *$ \\
\hline $\mathrm{D} \times \mathrm{N}$ & $*$ & $* * *$ & NS \\
\hline$Y \times D \times N$ & NS & $*$ & $*$ \\
\hline
\end{tabular}

${ }^{\dagger}$ Different letters within year, density or nitrogen indicate significant differences $(P<0.05)$. NS, no significant $(P>0.05)$. ${ }^{*}$ Significant at $P<0.05 .{ }^{* *}$ Significant at $P<0.01$. *** Significant at $P<0.001$

(Table 5). Interplant competition at high density contributes to reduced DMA per-plant (Tollenaar et al., 2006; Boomsma et al., 2009). However, maize biomass production at 90,000 plants $\mathrm{ha}^{-1}$ treatment increased under field level in the present study (Table 3), which is consistent with previous results of Lee and Tollenaar (2007) who found that higher biomass

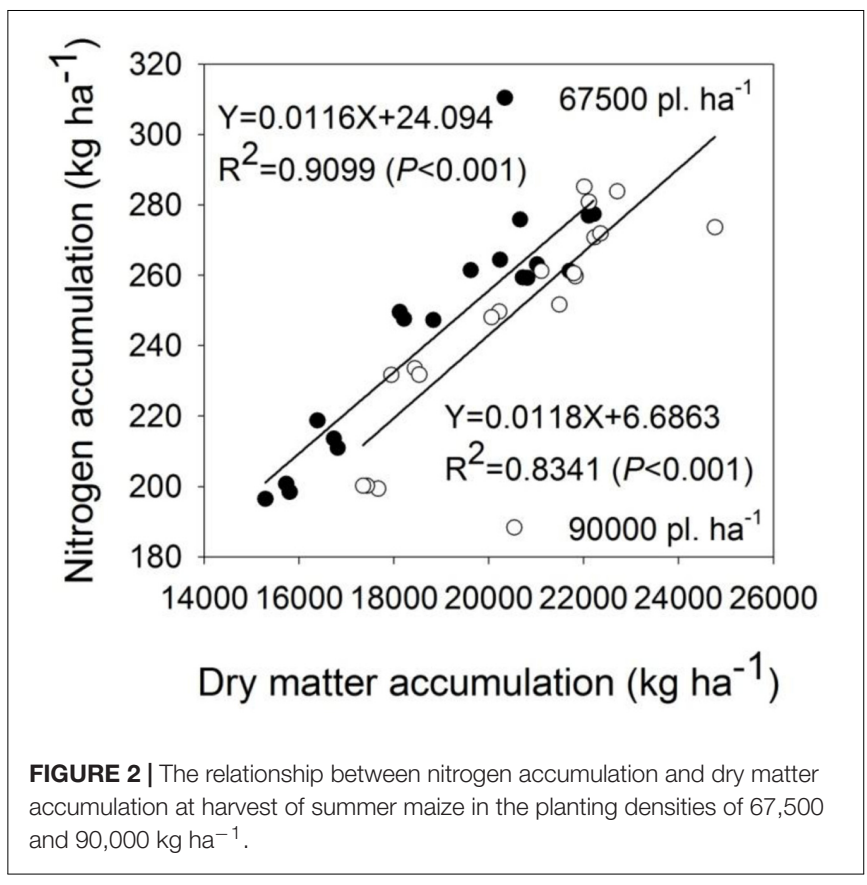

accumulations were obtained at relatively higher densities (75,000-90,000 plants ha $\left.{ }^{-1}\right)$, thus, a high rate of $\mathrm{N}$-uptake was observed in the positive relation between $\mathrm{N}$ accumulation and DMA. In addition, higher $\mathrm{N}$ concentration and accumulation were mainly due to higher $\mathrm{N}$ application rates (Liu et al., 2014). Not surprisingly, higher $\mathrm{N}$ accumulation was observed with a planting density of 90,000 plants $\mathrm{ha}^{-1}$ and the N360 treatments in this study.

Regarding N-transfer, we observed a decreased efficiency in $\mathrm{N}$ remobilization from vegetative organs to grains with increased rates of $\mathrm{N}$, and $\mathrm{N}$ remobilization and $\mathrm{N}$ remobilization

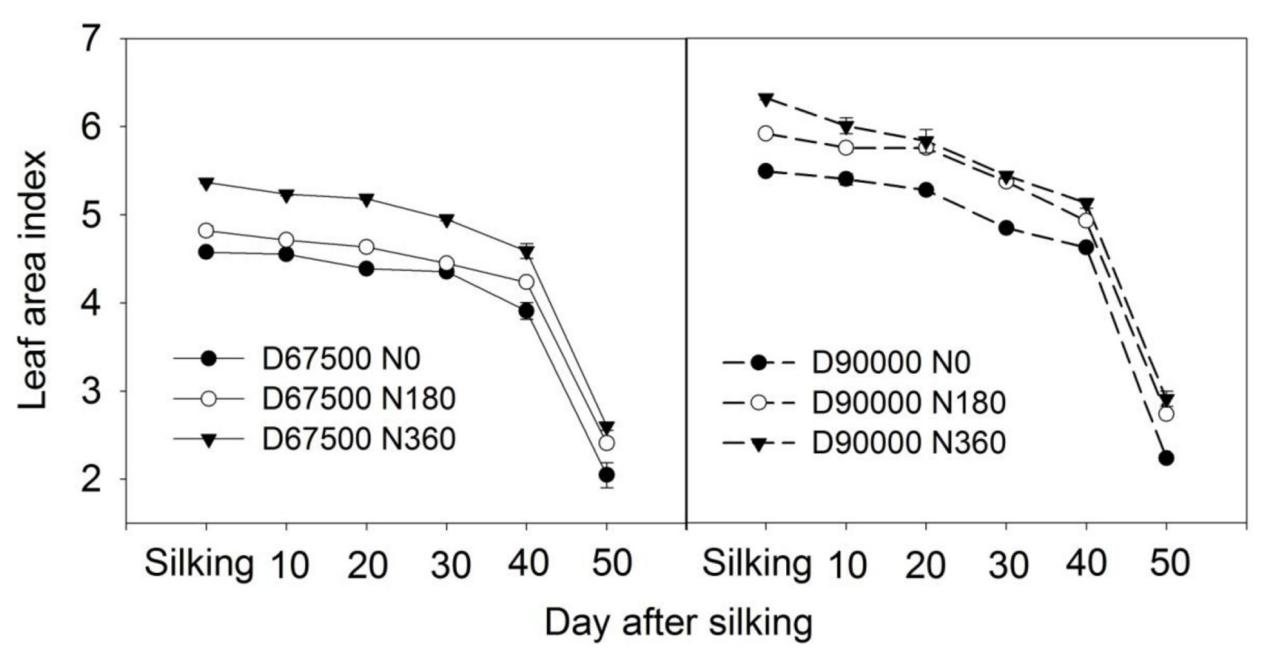

FIGURE 3 | Leaf area index of summer maize after silking for planting densities of 67,500 and 90,000 plants ha-1 and $\mathrm{N}$ treatments of 0 , 180 , and $360 \mathrm{~kg} \mathrm{~N}^{-1}$ in 2014 and 2015. D67500 and D90000 indicated 67,500 and 90,000 plants ha ${ }^{-1}$, respectively. N0, N180, and N360 indicated 0, 180 , and $360 \mathrm{~kg} \mathrm{~N} \mathrm{ha}^{-1}$, respectively. 


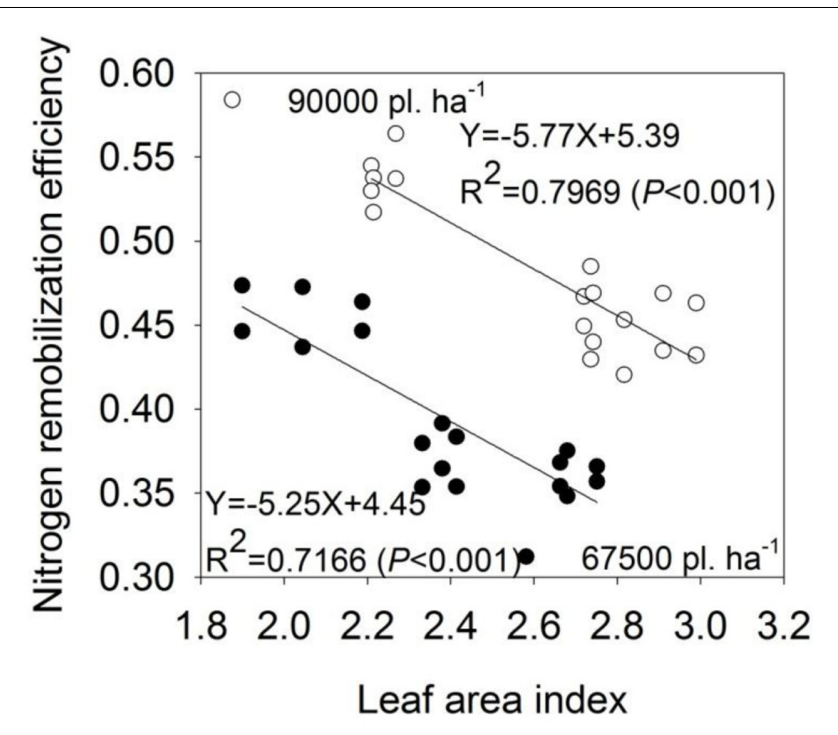

FIGURE 4 | The relationship between nitrogen remobilization efficiency and leaf area index at harvest of summer maize in the planting densities of 67,500 and $90,000 \mathrm{~kg} \mathrm{ha}^{-1}$.

efficiency improved under the higher planting density of summer maize (Table 4). Previous researchers indicated that 33-65\% of $\mathrm{N}$ concentrated in grains comes from $\mathrm{N}$ remobilization that was stored in vegetative organs before silking (Ciampitti and Vyn, 2013; Kosgey et al., 2013), especially the leaves, which contributed up to $45-65 \%$ (Chen Y. et al., 2014); N remobilization and $\mathrm{N}$ efficiency in our study were within those ranges, respectively (Table 4). Previous studies showed that high $\mathrm{N}$ application rates (e.g., 300 and $400 \mathrm{~kg} \mathrm{~N} \mathrm{ha}^{-1}$ ) contributed to the high $\mathrm{N}$ uptake capacity but low $\mathrm{N}$ remobilization efficiency because the leaves always maintained a "stay-green" state (Lee and Tollenaar, 2007; Ciampitti and Vyn, 2012). The negative correlation between $\mathrm{N}$ remobilization efficiency and LAI in this study reinforces the above conclusion (Figure 4). However, under relatively high planting densities (e.g., 90,000 plants $\mathrm{ha}^{-1}$ in this study), the $\mathrm{N}$ application for each plant was relatively low, and thus the $\mathrm{N}$ was not available in excess for each plant.

\section{Effects of Planting Density and Nitrogen Application Rate on $\mathrm{N}_{2} \mathrm{O}$ Emission Intensity and Greenhouse Gas Intensity}

Global $\mathrm{N}$ fertilizer consumption is expected to reach $250 \mathrm{Mt}$ $\mathrm{yr}^{-1}$ by 2050 (Tilman et al., 2011), which will lead to massive releases of greenhouse gas, water pollution, and other major environmental problems (Tilman et al., 2011; Lu and Tian, 2013). The future of agricultural production not only needs sustainable yield increases, but it must also limit environmental harm caused by excessive $\mathrm{N}$ application (Cui et al., 2013; Chen X. et al., 2014). We observed total $\mathrm{N}_{2} \mathrm{O}$ emissions of was 1.99 and $5.74 \mathrm{~kg} \mathrm{~N} \mathrm{ha}^{-1}$ in the recommended $\mathrm{N}$ management practice (N180; Liu et al., 2003) and the traditional $\mathrm{N}$ dose (N360) treatments, respectively;
TABLE 6 | $\mathrm{N}_{2} \mathrm{O}$ emission intensity and greenhouse gas intensity of summer maize for planting densities of 67,500 (D67500) and 90,000 plants ha ${ }^{-1}$ (D90000) and $\mathrm{N}$ treatments of 0 (NO), 180 (N180), and $360 \mathrm{~kg} \mathrm{~N} \mathrm{ha}^{-1}$ (N360) in 2014 and 2015.

\begin{tabular}{|c|c|c|c|c|}
\hline \multirow[t]{2}{*}{ Treatments } & \multicolumn{3}{|c|}{$\begin{array}{l}\mathrm{N}_{2} \mathrm{O} \text { emission intensity } \\
\left(\mathrm{kg} \mathrm{N} \mathrm{Mg}^{-1}\right)\end{array}$} & \multirow{2}{*}{$\begin{array}{c}\text { Greenhouse gas } \\
\text { intensity } \\
\left(\mathrm{kg} \mathrm{CO}_{2} \text { eq } \mathrm{Mg}^{-1}\right)\end{array}$} \\
\hline & Direct & Indirect & Total & \\
\hline \multicolumn{5}{|l|}{ Year } \\
\hline 2014 & $0.181 \mathrm{a}^{\dagger}$ & $0.077 \mathrm{a}$ & $0.258 a$ & $398.04 a$ \\
\hline 2015 & $0.173 b$ & $0.074 b$ & $0.247 b$ & $380.92 b$ \\
\hline \multicolumn{5}{|c|}{ Density (plants ha-1) } \\
\hline D67500 & $0.183 a$ & $0.078 \mathrm{a}$ & $0.262 a$ & $402.16 a$ \\
\hline D90000 & $0.171 b$ & $0.072 b$ & $0.243 b$ & $376.82 b$ \\
\hline \multicolumn{5}{|c|}{ Nitrogen (kg N ha-1) } \\
\hline No & $0.070 \mathrm{c}$ & $0.070 \mathrm{c}$ & $0.077 \mathrm{c}$ & $227.00 c$ \\
\hline N180 & $0.121 b$ & $0.055 b$ & $0.176 b$ & $329.43 b$ \\
\hline N360 & $0.341 a$ & $0.164 a$ & $0.505 a$ & $612.04 a$ \\
\hline \multicolumn{5}{|c|}{ Source of variation } \\
\hline Year $(Y)$ & * & * & $*$ & * \\
\hline Density (D) & $* * *$ & $* *$ & $* *$ & $* *$ \\
\hline Nitrogen (N) & $* * *$ & $* * *$ & $* * *$ & $* * *$ \\
\hline$Y \times D$ & NS & NS & NS & NS \\
\hline $\mathrm{Y} \times \mathrm{N}$ & NS & NS & NS & NS \\
\hline $\mathrm{D} \times \mathrm{N}$ & $* *$ & $* *$ & $* *$ & $*$ \\
\hline$Y \times D \times N$ & NS & NS & NS & NS \\
\hline
\end{tabular}

${ }^{\dagger}$ Different letters within year, density or nitrogen indicate significant differences $(P<0.05)$. NS, no significant $(P>0.05)$. *Significant at $P<0.05$. ** Significant at $P<0.01$. ${ }^{* *}$ Significant at $P<0.001$.

this also confirmed that excessive $\mathrm{N}$ fertilizer applications can lead to substantial fertilizer $\mathrm{N}$ losses with $\mathrm{N}$ entering ecosystems through nitrification-denitrification processes (Robertson and Vitousek, 2009; Sutton et al., 2011). The emission factor was $1.10 \%$ in N180 in our study, which was comparable to the $1.20 \%$ estimated by Cui et al. (2013) and $1.06 \%$ estimated by Linquist et al. (2012). The N180 treatment achieved similar GY with a $62 \%$ reduction in $\mathrm{N}_{2} \mathrm{O}$ emission intensity and a $46 \%$ reduction in greenhouse gas intensity compared to the N360 treatment (Table 6); we attributed this result to competitive GY. In addition, the $7 \%$ reduction in $\mathrm{N}_{2} \mathrm{O}$ emission intensity and a $4 \%$ reduction in greenhouse gas intensity in crops at a planting density of 90,000 plants ha ${ }^{-1}$ compared to 67,500 plants $\mathrm{ha}^{-1}$ were also attributed to the improved crop yields achieved through higher planting densities.

In the present study, compared with farmer practice, the labor costs in comprehensive management practice (increasing planting density and reducing $\mathrm{N}$ application) was increased, however, the $\mathrm{N}$ input was decreased with higher GY. In brief, the annual profit in comprehensive management practice increased by $¥ 503$ per ha compared with farmer practice. In actual maize production, field demonstrations of the revised fertilizer regime could be used to validate the research findings and be used to train farmers to ensure uptake of the new recommendations of best practice. 


\section{CONCLUSION}

Optimization of planting density (90,000 plants ha ${ }^{-1}$ ) and $\mathrm{N}$ application rate $\left(180 \mathrm{~kg} \mathrm{~N}^{-1}\right)$ resulted in the highest $\mathrm{N}$ utilization (NUE, AEN, and $\mathrm{PFP}_{\mathrm{N}}$ ) and $\mathrm{GY}$; it also lowered $\mathrm{N}_{2} \mathrm{O}$ emission intensity and greenhouse gas intensity of summer maize. The increase in $\mathrm{N}$ utilization was essentially due to the increased $\mathrm{N}$-uptake capacity and $\mathrm{N}$-transfer capacity. Therefore, higher planting densities and reduced $\mathrm{N}$ application rates should be considered to promote improved $\mathrm{N}$ utilization and GY with lower environmental costs in maize production.

\section{AUTHOR CONTRIBUTIONS}

PW and QM designed the study; CX, BT, and JR performed the study; CX, SH, and QM analyzed data and performed the statistical analyses; CX and QM wrote the paper.

\section{FUNDING}

This work was supported by the National Key Research and Development Program of China (2016YFD0300301) and the

\section{REFERENCES}

Andrade, F. H., Rizzalli, R., Della Maggiora, A., and Cassanovas, M. (2002). Kernel number prediction in maize under nitrogen or water stress. Crop Sci. 42, 1173-1179. doi: 10.2135/cropsci2002.1173

Boomsma, C. R., Santini, J. B., Tollenaar, M., and Vyn, T. J. (2009). Maize morphophysiological responses to intense crowding and low nitrogen availability: an analysis and review. Agron. J. 101, 1426-1452. doi: 10.2134/ agronj2009.0082

Borrás, L., Slafer, G. A., and Otegui, M. E. (2004). Seed dry weight response to source-sink manipulations in wheat, maize and soybean: a quantitative reappraisal. Field Crops Res. 86, 131-146. doi: 10.1016/j.fcr.2003.08.002

Bremner, J. M. (1965). Organic nitrogen in soils. Soil Nitrogen 10, 93-149. doi: 10.2134/agronmonogr10.c3

Burney, J. A., Davis, S. J., and Lobell, D. B. (2010). Greenhouse gas mitigation by agricultural intensification. Proc. Natl. Acad. Sci. U.S.A. 107, 12052-12057. doi: 10.1073/pnas.0914216107

Cassman, K. G., Dobermann, A., and Walters, D. T. (2002). Agroecosystems, nitrogen-use efficiency, and nitrogen management. Ambio 31, 132-140. doi: 10.1579/0044-7447-31.2.132

Chen, G. P., Wang, R. H., and Zhao, J. R. (2009). Analysis on yield structural model and key factors of maize high-yield plots. J. Maize Sci. 17, 89-93.

Chen, X., Cui, Z., Fan, M., Vitousek, P., Zhao, M., Ma, W., et al. (2014). Producing more grain with lower environmental costs. Nature 514, 486-489. doi: 10.1038/ nature 13609

Chen, X., Zhang, F., Römheld, V., Horlacher, D., Schulz, R., Böning-Zilkens, M. et al. (2006). Synchronizing $\mathrm{N}$ supply from soil and fertilizer and $\mathrm{N}$ demand of winter wheat by an improved Nmin method. Nutr. Cycl. Agroecosys. 74, 91-98. doi: 10.1007/s10705-005-1701-9

Chen, X. P., Cui, Z. L., Vitousek, P. M., Cassman, K. G., Matson, P. A., Bai, J. S. et al. (2011). Integrated soil-crop system management for food security. Proc. Natl. Acad. Sci. U.S.A. 108, 6399-6404. doi: 10.1073/pnas.1101419108

Chen, Y., Xiao, C., Chen, X., Li, Q., Zhang, J., Chen, F., et al. (2014). Characterization of the plant traits contributed to high grain yield and high grain nitrogen concentration in maize. Field Crops Res. 159, 1-9. doi: 10.1016/j. fcr.2014.01.002

Ciampitti, I. A., Murrell, S. T., Tuinstra, M., Camberato, J. J., Xia, Y., Friedemann, P., et al. (2013). Physiological dynamics of maize nitrogen
Special Fund for Agro-scientific Research in the Public Interest of China (201203031).

\section{SUPPLEMENTARY MATERIAL}

The Supplementary Material for this article can be found online at: http://journal.frontiersin.org/article/10.3389/fpls.2017.01234/ full\#supplementary-material

FIGURE S1 | Grain yield of summer maize for planting densities of 67,500 and 90,000 plants ha ${ }^{-1}$ and $\mathrm{N}$ treatments of 0,180 , and $360 \mathrm{~kg} \mathrm{~N} \mathrm{ha}^{-1}$ in 2014 and 2015.

FIGURE S2 | Nitrogen use efficiency (NUE), agronomic $\mathrm{N}$ efficiency (AEN), and $\mathrm{N}$ partial productivity $\left(\mathrm{PFP}_{\mathrm{N}}\right.$ ) of summer maize for planting densities of 67,500 and 90,000 plants ha ${ }^{-1}$ and $\mathrm{N}$ treatments of 0,180 , and $360 \mathrm{~kg} \mathrm{~N} \mathrm{ha}^{-1}$ in 2014 and 2015.

FIGURE S3 | Dry matter accumulation of summer maize at harvest for planting densities of 67,500 and 90,000 plants ha ${ }^{-1}$ and $\mathrm{N}$ treatments of 0,180 , and $360 \mathrm{~kg} \mathrm{~N} \mathrm{ha}^{-1}$ in 2014 and 2015.

FIGURE S4 | $\mathrm{N}_{2} \mathrm{O}$ emission intensity and greenhouse gas intensity of summer maize for planting densities of 67,500 and 90,000 plants ha ${ }^{-1}$ and $\mathrm{N}$ treatments of 0,180 , and $360 \mathrm{~kg} \mathrm{~N} \mathrm{ha}^{-1}$ in 2014 and 2015.

uptake and partitioning in response to plant density and N-stress factors: II. Reproductive phase. Crop Sci. 53, 2588-2602. doi: 10.2135/cropsci2013.01.0041

Ciampitti, I. A., and Vyn, T. J. (2012). Physiological perspectives of changes over time in maize yield dependency on nitrogen uptake and associated nitrogen efficiencies: a review. Field Crops Res. 133, 48-67. doi: 10.1016/j.fcr.2012.03.008

Ciampitti, I. A., and Vyn, T. J. (2013). Grain nitrogen source changes over time in maize: a review. Crop Sci. 53, 366-377. doi: 10.2135/cropsci2012.07.0439

Cui, Z., Yue, S., Wang, G., Meng, Q., Wu, L., Yang, Z., et al. (2013). Closing the yield gap could reduce projected greenhouse gas emissions: a case study of maize production in China. Glob. Change Biol. 19, 2467-2477. doi: 10.1111/gcb.12213

Cui, Z., Zhang, F., Mi, G., Chen, F., Li, F., Chen, X., et al. (2009). Interaction between genotypic difference and nitrogen management strategy in determining nitrogen use efficiency of summer maize. Plant Soil 317, 267-276. doi: $10.1007 / \mathrm{s} 11104-008-9807-\mathrm{x}$

Dobermann. (2005). "Nitrogen use efficiency - state of the art," in Proceedings of the IFA International Workshop on Enhanced-Efficiency Fertilizers, Frankfurt.

Foulkes, M. J., Hawkesford, M. J., Barraclough, P. B., Holdsworth, M. J., Kerr, S., Kightley, S., et al. (2009). Identifying traits to improve the nitrogen economy of wheat: recent advances and future prospects. Field Crops Res. 114, 329-342. doi: 10.1016/j.fcr.2009.09.005

Grassini, P., Thorburn, J., Burr, C., and Cassman, K. G. (2011). High-yield irrigated maize in the Western U.S. Corn Belt: I. On-farm yield, yield potential, and impact of agronomic practices. Field Crops Res. 120, 142-150. doi: 10.1016/j. fcr.2010.09.012

Guo, J. H., Liu, X. J., Zhang, Y., Shen, J. L., Han, W. X., Zhang, W. F., et al. (2010). Significant acidification in major Chinese croplands. Science 327, 1008-1010. doi: 10.1126/science. 1182570

Hoben, J. P., Gehl, R. J., Millar, N., Grace, P. R., and Robertson, G. P. (2011). Nonlinear nitrous oxide $\left(\mathrm{N}_{2} \mathrm{O}\right)$ response to nitrogen fertilizer in on-farm corn crops of the US Midwest. Glob. Change Biol. 17, 1140-1152. doi: 10.1111/j.13652486.2010.02349.x

IPCC (2006). "Agriculture, forestry and other land use," in Proceedings of the 2006 IPCC Guidelines for National Greenhouse Gas Inventories, Prepared by the National Greenhouse Gas Inventories Programme, eds S. Eggelston, L. Buendia, K. Miwa, T. Ngara, and K. Tanabe (Hayama: IGES), 11.1-11.54.

Keyzer, M. A., Merbis, M. D., Pavel, I. F. P. W., and van Wesenbeeck, C. F. A. (2005). Diet shifts towards meat and the effects on cereal use: Can we feed the animals in 2030? Ecol. Econ. 55, 187-202. doi: 10.1016/j.ecolecon.2004.12.002 
Kosgey, J. R., Moot, D. J., Fletcher, A. L., and McKenzie, B. A. (2013). Dry matter accumulation and post-silking $\mathrm{N}$ economy of 'stay-green' maize (Zea mays L.) hybrids. Eur. J. Agron. 51, 43-52. doi: 10.1016/j.eja.2013.07.001

Lawlor, D. W., and Cornic, G. (2002). Photosynthetic carbon assimilation and associated metabolism in relation to water deficits in higher plants. Plant Cell Environ. 25, 275-294. doi: 10.1046/j.0016-8025.2001.00814.x

Lee, E. A., and Tollenaar, M. (2007). Physiological basis of successful breeding strategies for maize grain yield. Crop Sci. 47, S202-S215. doi: 10.2135/ cropsci2007.04.0010IPBS

Li, H., Lin, H., Liang, S., Zhao, H., and Wang, J. (2012). Effects of planting densities and modes on activities of some enzymes and yield in summer maize. Acta Ecol. Sin. 32, 6584-6590. doi: 10.5846/stxb201203050294

Li, S. K., and Wang, C. T. (2009). Evolution and development of maize production techniques in China. Sci. Agric. Sin. 42, 1941-1951.

Linquist, B., van Groenigen, K. J., Adviento-Borbe, M. A., Pittelkow, C., and van Kessel, C. (2012). An agronomic assessment of greenhouse gas emissions from major cereal crops. Glob. Change Biol. 18, 194-209. doi: 10.1111/j.1365-2486. 2011.02502.x

Linquist, B. A., Liu, L., Kessel, C. V., and Groenigen, K. J. V. (2013). Enhanced efficiency nitrogen fertilizers for rice systems: meta-analysis of yield and nitrogen uptake. Field Crops Res. 154, 246-254. doi: 10.1016/j.fcr.2013.08.014

Liu, J. L., Zhan, A., Bu, L. D., Zhu, L., Luo, S. S., Chen, X. P., et al. (2014). Understanding dry matter and nitrogen accumulation for high-yielding filmmulched maize. Agron. J. 106, 390-396. doi: 10.2134/agronj2013.0404

Liu, X. J., Ju, X. T., Zhang, F. S., Pan, J. R., and Christie, P. (2003). Nitrogen dynamics and budgets in a winter wheat-maize cropping system in the North China Plain. Field Crops Res. 83, 111-124. doi: 10.1016/S0378-4290(03)00068-6

$\mathrm{Lu}, \mathrm{C}$., and Tian, H. (2013). Net greenhouse gas balance in response to nitrogen enrichment: perspectives from a coupled biogeochemical model. Glob. Change Biol. 19, 571-588. doi: 10.1111/gcb.12049

Meng, Q., Hou, P., Wu, L., Chen, X., Cui, Z., and Zhang, F. (2013). Understanding production potentials and yields gaps in intensive maize production in China. Field Crops Res. 143, 91-97. doi: 10.1016/j.fcr.2012.09.023

Mi, G. H., Liu, J. A., Chen, F. J., Zhang, F. S., Cui, Z. L., and Liu, X. S. (2003). Nitrogen uptake and remobilization in maize hybrids differing in leaf senescence. J. Plant Nutr. 26, 237-247. doi: 10.1007/0-306-47624-X_32

Miao, Y. X., Stewart, B. A., and Zhang, F. S. (2011). Long-term experiments for sustainable nutrient management in China. A review. Agron. Sustain. Dev. 31, 397-414. doi: 10.1051/agro/2010034

Moll, R. H., Kamprath, E. J., and Jackson, W. A. (1982). Analysis and interpretation of factors which contribute to efficiency of nitrogen utilization. Agron. J. 74, 562-564. doi: 10.2134/agronj1982.00021962007400030037x

Montgomery, E. G. (1911). Correlation studies in corn. Neb. Agric. Exp. Stn. Annu. Rep. 24, 108-159.

NCGA (2017). National Corn Yield Contest, NCGA's Best in the Field. Available at: http://dtnpf-digital.com/publication/?i=288631

Olsen, S. R., Cole, C. L., Watanabe, F. S., and Dean, L. A. (1954). Estimation of Available Phosphorus in Soils by Extraction with Sodium Bicarbonate. Washington, DC: USDA, 72-75.

Pikul, J. L., Hammack, L., and Riedell, W. E. (2005). Corn yield, nitrogen use, and corn rootworm infestation of rotations in the northern corn belt. Agron. J. 97, 854-863. doi: 10.2134/agronj2004.0263

Piper, C. S. (1950). Soil and Plant Analysis. Adelaide, SA: The University of Adelaide.

Rajcan, I., and Tollenaar, M. (1999). Source: sink ratio and leaf senescence in maize. II. Nitrogen metabolism during grain filling. Field Crops Res. 60, 255-265. doi: 10.1016/S0378-4290(98)00143-9

Raun, W. R., and Jhonson, V. G. (1999). Improving nitrogen use efficiency for cereal production. Agron. J. 91, 357-363. doi: 10.2134/agronj1999. $00021962009100030001 \mathrm{x}$

Robertson, G. P., and Vitousek, P. M. (2009). Nitrogen in agriculture: balancing the cost of an essential resource. Annu. Rev. Environ. Resour. 34, 97-125. doi: 10.1146/annurev.environ.032108.105046

Shen, L., Wang, P., Lan, L., and Sun, X. (2007). Effect of nitrogen supply on carbonnitrogen metabolism and kernel set in summer maize. Plant Nutr. Fertil. Sci. 13, 1074-1079.
Shiferaw, B., Prasanna, B., Hellin, J., and Bänziger, M. (2011). Crops that feed the world 6. Past successes and future challenges to the role played by maize in global food security. Food Sec. 3, 307-327. doi: 10.1007/s12571-0110140-5

Stanford, S., and English, L. (1949). Use of flame photometer in rapid soil tests for K and Ca. Agron. J. 41, 446-447. doi: 10.2134/agronj1949. $00021962004100090012 x$

Sutton, M. A., Oenema, O., Erisman, J. W., Leip, A., van Grinsven, H., and Winiwarter, W. (2011). Too much of a good thing. Nature 472, 159-161. doi: $10.1038 / 472159$ a

Sylvester-Bradley, R., and Kindred, D. R. (2009). Analysing nitrogen responses of cereals to prioritize routes to the improvement of nitrogen use efficiency. J. Exp. Bot. 60, 1939-1951. doi: 10.1093/jxb/erp116

Tester, M., and Langridge, P. (2010). Breeding technologies to increase crop production in a changing world. Science 327, 818-822. doi: 10.1126/science. 1183700

Tilman, D., Balzer, C., Hill, J., and Befort, B. L. (2011). Global food demand and the sustainable intensification of agriculture. Proc. Natl. Acad. Sci. U.S.A. 108, 20260-20264. doi: 10.1073/pnas.1116437108

Tokatlidis, I. S., Has, V., Melidis, V., Has, I., Mylonas, I., Evgenidis, G., et al. (2011). Maize hybrids less dependent on high plant densities improve resource-use efficiency in rainfed and irrigated conditions. Field Crops Res. 120, 345-351. doi: 10.1016/j.fcr.2010.11.006

Tollenaar, M., Deen, W., Echarte, L., and Liu, W. (2006). Effect of crowding stress on dry matter accumulation and harvest index in maize. Agron. J. 98, 930-937. doi: 10.2134 /agronj2005.0336

Tollenaar, M., and Lee, E. A. (2002). Yield potential, yield stability and stress tolerance in maize. Field Crops Res. 75, 161-170. doi: 10.1016/S0378-4290(02) 00024-2

Tolley-Henry, L., Raper, C. D. Jr., and Granato, T. C. (1988). Cyclic variations in nitrogen uptake rate of soybean plants: effects of external nitrate concentration. J. Exp. Bot. 39, 613-622. doi: 10.1093/jxb/ 39.5.613

Troyer, A. F., and Rosenbrook, R. W. (1983). Utility of higher plant densities for corn performance testing. Crop Sci. 23, 863-867. doi: 10.2135/cropsci1983. 0011183X002300050011x

Van Ittersum, M. K., and Cassman, K. G. (2013). Yield gap analysis-rationale, methods and applications? Introduction to the special issue. Field Crops Res. 143, 1-3. doi: 10.1016/j.fcr.2012.12.012

Van Ittersum, M. K., Cassman, K. G., Grassini, P., Wolf, J., Tittonell, P., and Hochman, Z. (2013). Yield gap analysis with local to global relevance-a review. Field Crops Res. 143, 4-17. doi: 10.1016/j.fcr.2012.09.009

Wang, C., Li, X., Gong, T., and Zhang, H. (2014). Life cycle assessment of wheatmaize rotation system emphasizing high crop yield and high resource use efficiency in Quzhou County. J. Clean. Prod. 68, 56-63. doi: 10.1016/j.jclepro. 2014.01.018

Zhang, F. S., Wang, J. Q., Zhang, W. F., Cui, Z. L., Ma, W. Q., Chen, X. P., et al. (2008). Nitrogen use efficiencies of major cereal crops in China and measures for improvement. Acta Pedol. Sin. 45, 915-924.

Zhang, X., Davidson, E. A., Mauzerall, D. L., Searchinger, T. D., Dumas, P., and Shen, Y. (2015). Managing nitrogen for sustainable development. Nature 528, 51-59. doi: 10.1038/nature15743

Zhao, J. R., and Wang, R. H. (2009). Factors promoting the steady increase of American maize production and their enlightenments for China. J. Maize Sci. $17: 163$.

Conflict of Interest Statement: The authors declare that the research was conducted in the absence of any commercial or financial relationships that could be construed as a potential conflict of interest.

Copyright (๑) 2017 Xu, Huang, Tian, Ren, Meng and Wang. This is an open-access article distributed under the terms of the Creative Commons Attribution License (CC BY). The use, distribution or reproduction in other forums is permitted, provided the original author(s) or licensor are credited and that the original publication in this journal is cited, in accordance with accepted academic practice. No use, distribution or reproduction is permitted which does not comply with these terms. 